\title{
Philosophy of Hidden Curriculum in the Crossroad Between Professionals' Thinking and Action: Adult Education Curriculum
}

\author{
Anita Jug Došler \\ Development and Research Department, Slovenian Institute for Adult Education (SIAE), Ljubljana, Slovenia \\ Email address: \\ anita1.jug@gmail.com \\ To cite this article: \\ Anita Jug Došler. Philosophy of Hidden Curriculum in the Crossroad Between Professionals' Thinking and Action: Adult Education \\ Curriculum. Education Journal. Vol. 10, No. 3, 2021, pp. 107-113. doi: 10.11648/j.edu.20211003.16
}

Received: June 9, 2021; Accepted: June 23, 2021; Published: June 30, 2021

\begin{abstract}
Theoretical background: An awareness of the operation of factors of the hidden curriculum is a precondition for an effective and professional adult education practice. A hidden curriculum comes to bear on the work process, content, procedures and routines, it can also be understood as the "battleground" of various competing influences and ideologies that appears in a hidden manner. Method: We use the meta-synthesis research design. The main goal of a meta-synthesis was building theory by refining or extending existing theory and generating a new theory. Results: On the basis of the research findings, we develop guidelines for researching and directing the hidden curriculum and subjective theories that are based on action research, evaluation research and research following the method of the deconstruction and redefinition of the personal thinking and beliefs that guide the individual's professional activity on the basis of processes of critical awareness and reflection. Conclusion: Deconstruction and redefinition of the personal thinking and beliefs that direct the individual's professional operation and action are very important processes of individual professionalism. We should be aware that the researching and directing the factors of hidden curriculum can help and improve the quality of adult education and practice, professional work and operation in the education process and outcomes for practitioners.
\end{abstract}

Keywords: Hidden Curriculum, Adult Education, Reflection, Adult Practice

\section{Introduction and Importance of the Problem}

The study presents some new aspects, conceptual and methodological, of researching and directing the hidden curriculum in the field of adult education curriculum. Researching and directing the hidden curriculum is a permanent process in which we determine both its good and bad sides. This process is being improved on the basis of new findings. It is important to be aware that the hidden curriculum is not always negative, and that it enables us to realise things that are not in fact regulated by official documents. In the process of identification, we constantly strive: (1) to identify those factors of quality that we are able to transfer to other contents, (2) to understand how various approaches, procedures, methods, content and forms of work function in the work environment, (3) to determine the quality and/or efficiency of adult education programme or practice, (4) to identify spontaneous, routine activities and other rules of existence and operation in the institution. Since there is no programme or practice in which values and beliefs are absent, we cannot research and direct the hidden curriculum outside the field of subjective theories. Both the hidden curriculum and subjective theories are positioned beneath power relations and the socio-cultural context in which professionals live and work, as well as beneath their personal history of life and their professional knowledge and experience. The experience of older professionals largely influences the fact that the 'routines of the hidden curriculum' are transferred to the subjective theories of young people or new employees [15]. In this regard, Pajares [27] points out that a person's subjective knowledge can be greatly influenced precisely by own beliefs, which can even distort or transform information and thought process. This also plays an important role in recognising, perceiving and 
interpreting knowledge when we plan and decide upon own responses. Interconnected beliefs form themselves into subjective theories, and their influence can persist even on the presentation of scientific and professionally founded specific explanations, which is why their modification is a long-lasting, individual and comprehensive process $[31,26$, $17,25]$.

\section{Background}

The beginnings of research into the hidden curriculum in the 1960s are attributed to Jackson [14], although the conceptual study of the hidden curriculum really commenced with Dewey [6]. Apple [1,2] and Gerbner [10] are also amongst the most prominent researchers of the hidden curriculum. According to Gerbner [10], in every institution a hidden curriculum is realised alongside the official curriculum. Gerbner claims that the hidden curriculum works in such a way that, on the basis of the common institutional ways of operation of institution, particular stereotypical social behaviours and responses are established that influence the functioning of the individual. He goes on to emphasise that the hidden curriculum of an institution is also linked with the hidden curriculum of a particular society, which contains a body of established rules, norms or cultural patterns. In adult education practices, the hidden curriculum thus occupies the place of an ideological element/factor where identities of the symbolic framework of social order are appropriated. Each culture, each institution, strives for an organisation of cognition and operation that conforms with the social patterns that determine its existing social order [15, 16]. Authors Apple [2], N. R. King [20] and A. V. Kelly [19] believe that the hidden curriculum has been, and continues to be, of interest to politics and various ideologies; there have always been tendencies to instrumentalise the hidden curriculum and misuse it for purposes that may or may not be in line with official adult education or practice goals and values. We can, therefore, view the hidden curriculum as a "battleground" of numerous competing influences and ideologies. Although there is frequently resistance to these influences and ideologies, it is precisely for this reason that they emerge in institutions in the form of the hidden curriculum. Many factors of the hidden curriculum are frequently derived from the individual professional subjective theories, which are not appropriately reflected upon and professionally justified. In addition to factors of the hidden curriculum, it is also worrying if the curriculum remains hidden precisely due to the purposes and reasons of manipulation, in the background of which stand either political-technological or academic interests, in the sense of retaining social or professional ideologies (in the field of andragogy and pedagogy, developmental and clinical psychology, various orientations of medical science, etc.) $[20,15,11,24,22]$. For example, in adult academic concepts of developmentalism, social ideology is evident in tendencies towards the standardisation of the individual's development, whereby the profession affirms particular concepts that primarily serve ideological practices of classifying individuals on the continuum of the normality and pathology of their personality capabilities and developmental characteristics. This has a very tangible influence on professional practice $[32,22,25]$. It is therefore all the more important that the individual is capable of deconstructing, critically analysing and appropriately orienting own ways of thought and operation, as well as those that are institutional or perhaps politically and ideologically "coloured" [32], 22], $4,12]$. Many authors $[29,24,21,22,18,34,25]$ state that the hidden curriculum is determined by factors such as: social relationships; interaction and communication; the social and emotional response of professionals to the needs of individuals and their understanding of differences between individuals; the education of procedures, rules and principles that staff members can readily adopt; the hidden expectations of professionals and their personality dispositions; special ways of socialising and disciplining; professionals as objects of identification; the work process, content, procedures and routines; monitoring education and education effects and the self-evaluation of education practice; work rules and time organisation; the organisation of work and habitation in education; counselling and professional support provided to professionals; cooperation between employees in planning, implementing and evaluating adult education practice and interventions; employee's opportunities for continuing education; cooperation and teamwork, etc. Based on the above, we can conclude that the hidden curriculum comes to bear on the education process, content, procedures and methods, as well as the organisation of adult education, practice, procedures and rituals. It can also be understood as the "battleground" of various competing influences and ideologies that appears in a hidden manner. The key factor in this regard, however, is whether the individual or the adult educational institution is capable of recognising, reflecting on and, to the best of their powers, modifying or directing the hidden curriculum. Thus the hidden curriculum is an important factor that embraces various elements of the direct and indirect influence and operation of the individual and group within a particular institution.

\section{Operation of the Hidden Curriculum}

In the continuation, we present the way in which the factors of the hidden curriculum and subjective theories operate upon the individual and the institution. As an example of the interweaving of the operation of social ideologies (regimes of truth), subjective theories and the hidden curriculum, we first outline Foucault's conception. Foucault $[13,22]$ explains the functioning of the hidden curriculum through governmentality, presuming that it operates on the individual in the context of social control, norms and power. He claims that the hidden curriculum is never static, as it is constantly socially constructed through interactions in which it is impossible for it to be known objectively, since it is dependent on the value systems, beliefs, and socio-historical and cultural circumstances that determine the individual's social space and functioning. According to Foucault [22], the theory of poststructuralism 
highlights the structural characteristics of intentional education and socialisation, which are linked with the submission of the individual to the specific demands of authority. In order to further justify the need to adapt the individual to the social conditions, authority frequently engages the support of the regimes of truth created by normative sciences, including the aforementioned developmental psychology, andragogy, pedagogy and various branches of scientific knowledge. Regimes of truth subtly establish themselves in the environments in which institutions operate on the declarative principles of professional autonomy, as the more open opportunities for creating curricular solutions also enable the infiltration of non-professional elements $[21,29,34,28]$. In Foucault's view, emancipation from the influence of the (socio)cultural patterns, norms and prevailing social ideologies that cause a shift from the official curriculum lies in activism, in the deconstruction of one's own mental schemes and the constructs that orient the functioning of the individual through a critical awareness of one's own thinking [22]. Based on analysis and critical thinking, deconstruction is a postmodern approach whose key purpose is to demonstrate the multilayered nature of various statements, perceptions, beliefs, issues and contradictions. It means the reversal and removal of concepts and the subsequent establishment of a renewed construct. It means a form of analysis that exposes the numerous possible meanings, contradictions and assumptions of our understanding and operation linked to specific adult educational situations. Deconstruction reveals the 'others' and their policies, exposing inner contradictions, particularly between systems of thought that form the basis of the individual's behavior and understanding of the established, or their own adult education practices that can be accepted as entirely self-evident, in the style of "because everyone does it, I do it too" [7, 13, 34]. Each institution, each society, is linked with the power relations and interests that produce regimes of truth. It is interesting to be aware of the areas or levels in which they can be recognised or sought. The political content of regimes of truth is comprised of the practice of power and norms that sustain the regime. The factors of subjective theories and the hidden curriculum frequently cause adult education, socialisation and learning effects that are subtle, unplanned side products of the (planned) adult education work [5], 26, 3]. These effects are often more efficient and difficult to trace, as they cannot be easily recognised, differentiated and changed $[8,12]$.

Through a review of the concept of the hidden curriculum, we have shown that: (1) the factors of the hidden curriculum often refer to elements of routine activities that can be favoured by an individual or institution, (2) greater professional autonomy of employees also represents a greater danger for the operation of the factors of the hidden curriculum, (3) social ideologies are transferred to subjective theories, and their modification and directing is a precondition to increasing the quality of the adult education of employees. In the continuation we present the findings of research aimed at creating a new model for researching and directing the hidden curriculum.

\section{Purpose of the Review}

In the article we presuppose that an awareness of the operation of factors of the hidden is a precondition for quality adult education practice. Empirical part of the study is designed as a case study. Critical literature and research review was used as a descriptive method. Relevant data was processed with meta-synthesis principles. On the basis of the research findings, we develop guidelines for researching and directing the hidden curriculum witch can contribute to raising the quality of the adult education practice of employees in the adult education fields and sectors.

\section{Methodology}

The present research is based on a case study methodology. A case study is defined as empirical research that examines a contemporary phenomenon in the context of the real environment, and includes a comprehensive and detailed collection of data from multiple sources of information [36]. In terms of content criteria, the present study, in which both interpretive and causal paradigms interweave, is an example of an educational study, as it strives for an understanding of adult education activities [30]. Inference takes place on the basis of analytical induction [36], within the framework of which we have studied how individual characteristics, processes and/or activities are interconnected, and what kind of attitudes or relationships they have to each other.

The data were processed according to the meta-synthesis research design by combining different research methods: the description method, the classification method, the method of compilation and the method of comparison. The following databases were examined: Google Scholar, Elseviever, Cochrane Library, ScienceDirect, ProQuest, ERIC, Midirs, Embase and COBIB.SI, as well as the federated search engines DiKul and Athens. The selection of results in scientific databases was limited to the following selection criteria: accessibility, scientific basis, suitability of the content with regard to the purpose of the present research, and whether the source was up to date and current. Studies were assessed according to methodological quality and analysed according to the studied parameters and results. Cross-sectional, longitudinal, prospective and comparative studies were used for the analysis. The review of literature and research results was undertaken from September 2014 to April 2017.

\section{Findings}

The studies have been evaluated in terms of quality on the basis of a four-level scale, created with regard to the type of research and the strength of evidence (Table 1). The studies labelled I have the highest reliability of evidence, while those with the lowest reliability of evidence are labelled IV [9]. 
Table 1. Methodological rating of the analysed studies [9].

\begin{tabular}{ll}
\hline Category & Methodology of study \\
\hline I & Evidence obtained from a systematic review of meta-analyses from randomised control research studies or at least one randomised control study. \\
II & Evidence obtained from at least one control study without randomisation or at least one quasi-experimental study of another type. \\
III & Evidence obtained from non-experimental, descriptive studies such as comparative studies, correlation studies and case studies. \\
IV & Evidence obtained from reports by expert groups, or the opinion and/or clinical/educational experience of a respected authority. \\
\hline
\end{tabular}

Most of the studies found were from categorie III $(\mathrm{n}=8)$. Only a small number of studies belonging to categories I $(\mathrm{n}=1)$ and II $(\mathrm{n}=2)$. In categorie IV there are two studies (see Table 2).

Table 2. Evaluation of the analysed studies according to the four-level scale.

\begin{tabular}{|c|c|c|}
\hline Author & Quality rate of research & Type of research methodology with research techniques and tools \\
\hline Apple [1] & I & $\begin{array}{l}\text { Quantitative and qualitative methodology: } \\
\text { research diary } \\
\text { interviews } \\
\text { analysis of observations with notes }\end{array}$ \\
\hline MacNaughton [22] & II & $\begin{array}{l}\text { Quantitative and qualitative methodology: } \\
\text { analysis of documentation of primary and secondary sources } \\
\text { observations } \\
\text { ethnographic reports }\end{array}$ \\
\hline Shorey [34] & III & $\begin{array}{l}\text { Quantitative and qualitative methodology: } \\
\text { observations } \\
\text { interviews } \\
\text { questionnaires }\end{array}$ \\
\hline Tuden et al. [33] & III & $\begin{array}{l}\text { Qualitative methodology: } \\
\text { analysis of documentation of primary and secondary sources }\end{array}$ \\
\hline Mossop et al. [25] & III & $\begin{array}{l}\text { Qualitative methodology: } \\
\text { focus groups } \\
\text { questionnaire }\end{array}$ \\
\hline Kroflič [21] & III & $\begin{array}{l}\text { Qualitative methodology: } \\
\text { analysis of documentation of primary and secondary sources } \\
\text { ethnographic reports }\end{array}$ \\
\hline Norris [26] & III & $\begin{array}{l}\text { Qualitative methodology: } \\
\text { reflections of practice } \\
\text { group meetings } \\
\text { focus groups }\end{array}$ \\
\hline Higashi et al. [12] & III & $\begin{array}{l}\text { Qualitative methodology: } \\
\text { interviews }\end{array}$ \\
\hline Gerbner [10] & III & $\begin{array}{l}\text { Quantitative and qualitative methodology: } \\
\text { research diary } \\
\text { interviews } \\
\text { observations with notes }\end{array}$ \\
\hline Turnšek [35] & IV & $\begin{array}{l}\text { Quantitative and qualitative methodology: } \\
\text { interviews } \\
\text { questionnaires } \\
\text { analysis of primary and secondary documents }\end{array}$ \\
\hline Chretien [4] & II & $\begin{array}{l}\text { Quantitative and qualitative methodology: } \\
\text { analysis of primary and secondary documents }\end{array}$ \\
\hline Moor [23] & IV & $\begin{array}{l}\text { Quantitative and qualitative methodology: } \\
\text { focus groups } \\
\text { questionnaires }\end{array}$ \\
\hline Pajares [27] & III & $\begin{array}{l}\text { Quantitative and qualitative methodology: } \\
\text { analysis of primary and secondary documents } \\
\text { consultations }\end{array}$ \\
\hline
\end{tabular}

In spite of the fact that there is an inadequate number of randomised and longitudinal studies, we can, on the basis of a systematic review of studies from the area of researching and directing the factors of the hidden curriculum, conclude that the majority of studies use the descriptive and causal non-experimental method of empirical research, and that the studies were designed on the basis of a quantitative and qualitative methodology. The studies were mainly undertaken on smaller samples, and their findings, conclusions and results are therefore contextually linked to the specific research environment of an institution. The data collection techniques most frequently used by the researchers were: surveys with questionnaires, observations, interviews and analysis of documents. The researchers were also used research diaries, ethnographic reports, analysis of medical documentation, etc.

The findings of our research show that researching and directing the factors of the hidden curriculum does not have 
universal and uniform research methodologies. Institutions in which the adult education process takes place in Europe and throughout the world are very different, from the legal regulation and regulation of the education system in particular country, as well as from the perspective of the prevailing role of the institution: educational and developmental. This means that the concept of quality adult education in connection with the hidden curriculum cannot be established and verified from the perspective of uniformed standards, goals and methods of research (for example: [27, $23,12,33]$. The problem is also in that there are no uniformed concepts of the hidden curriculum, which could clearly defined content and structural fields of the place where the hidden curriculum could be recognised in a particular institution.

From the perspective of content structuring of researching and directing the hidden curriculum, the studies can be splited into 4 groups:

(1) Studies (for example: [1, 22, 35, 33]) that investigated how the masing social ideologies have influenced the operation of institutions and the behaviours of employees through hidden curriculum. Common to these studies is the point that social ideology is something that which is 'transferred' to the subjective employees' theories, directing the hidden curriculum towards away from the formal curriculum, formal documents and legislation.

(2) Studies (for example: $[10,27,25,12]$ ) that investigated the effect of the social and cultural environment and other factors on the formation of subjective theories and the hidden curriculum. In these studies, we can recognize that social and cultural factors in different institutions determine both the individual's social environment and direct his or her professional action.

(3) Studies (for example: [1, 26, 34, 4, 12]) investigated parts where the hidden curriculum can be recognised, despite the fact that in some of these studies researching the hidden curriculum was not a central goal. In these studies, we can recognize that the hidden curriculum can be found at parts such as: the adult education process, content of adult education, in activity and organisation procedures; in the organisational or personal daily routine; in relationships and communication between employees, as well as ways of socialising and disciplining; the understanding of response and action to individual differences, and the realisation of the possibility of choice between employees and between others in the adult education process.

(4) Studies (for example: [22, 23, 12]) designed as developmental action research, which were researching how the factors of the hidden curriculum and subjective theories effect on the adult education process and practical experiences, also research their systematic changing and directing (there focus was changing the hidden curriculum). These studies are developing new education practice, programmes, activities and procedures, adult education methods and didactic, etc., and improving existing ones. This kind of the research produced some new findings, or the updating of existing findings, regarding the phenomena studied, while at the same time following applicative goals, practices and purposes.

A review of the literature and results of the studies about content structuring, research aims and methodological approach about researching the hidden curriculum has led us to conclude that studies are based on participatory research, of which can be traced the elements of action research, evaluation research, research of the deconstruction and redefinition of the personal thinking and beliefs that direct the individual's professional actions on the basis of processes of reflection critical awareness. The results show that the factors of the hidden curriculum cannot be excluded. It is important to deal with them and imbue with real meaning and embedding them in the planning and evaluation of adult education and practice. Quality assurance of adult education and practice have to include researching and directing the hidden curriculum. And this process can only be ensured when it is derived from practitioners on adult education field who possessing appropriate knowledge and behaviours, reflect and evaluate the adult education process and their role in it, with professional support and through processes of monitoring, directing and reflection.

\section{Conclusions}

On the basis of a review of the existing literature and the results of our study, we have demonstrated that researching and directing the hidden curriculum is a comprehensive process that concerns both the individual and the institution in which we are employed. If we directly monitor the professional operation of employees, we can determine: the laws according to which they work; the rules of behaviour that exist as social and developmental norms; the subjective theories linked to specific behaviours, which we confront with declarative theories through an insight into the context. Evaluation of this process directs the individual professional towards the establishment of a grounded theory, where by the transfer of this practice to new frameworks presupposes an understanding of the contextual conditions of the new frameworks and includes reflection on the consequences that it has for the application of current practices in the new context. The methods and techniques of researching the hidden curriculum aid employees in recognising and changing subjective theories and directing the hidden curriculum. The hermeneutic-dialectic circle in constructivist-naturalistic evaluation helps employees to strengthen common viewpoints and strategies, encouraging behaviours and responses that are aligned with the agreed goals and strategies of adult education operation. In the background of this, a process unfolds that is similar to the formation of a grounded theory. So, through this article we have shown that this process is effective if it is based on 
action research, reflection, evaluation research and research of the deconstruction and redefinition of the personal thinking and beliefs, institutional routine and the subjective viewpoints of employees that direct the individual's professional operation and action. We can conclude that deconstruction and redefinition of the personal thinking and beliefs that direct the individual's professional operation and action are very important processes of individual professionalism in adult education field, which can help and improve the quality assurance of adult education and practice, professional work and operation in the education process and outcomes for practitioners.

\section{Declaration}

The author declares that no conflicts of interest exist. The study received no funding. The study is original and it is not under consideration by another publisher. Author confirms that the procedures followed in the manuscript were in accordance with the copyright and ethical standards of the journal.

\section{Appendix}

Slovenian Institute for Adult Education (SIAE) draft professional bases and evaluations, and monitors the development of the adult education system, develops various non-formal and formal forms of learning, develops programs to improve adult literacy, and pays particular attention to improving access by vulnerable groups of adults to education and learning. In doing so, it develops the necessary infrastructure to support learning, develops models for the self-evaluation of quality and the validation of prior learning, and provides professional education and training for adult educators. SIAE is the main national institution for research and development, quality and education, guidance and validation, and promotional and informative activities in the field of adult education in Slovenia.

\section{References}

[1] Apple, W. M., (1979). Ideology and Curriculum. Boston, MA: Routledge \& Kegan Paul.

[2] Apple, W. M., (1992). Šola, učitelj in oblast. Ljubljana: Znanstveno in publicistično središče.

[3] Chisholm, M. E. (2016). Book Review: Hegemony and Education Under Neoliberalism: Insights From Gramsci, by P. Mayo. Adult Education Quarterly, 67 (3), 243-245.

[4] Chretien, C. K. (2013). Teaching and learning moments: the other hidden curriculum. Acad Med, 288 (2), 289.

[5] Corbett, J. (1992). Careful teaching: researching a special career. British Educational Journal, 18 (2), 235-243.

[6] Dewey, J. (1916). Democracy and education: An introduction to the philosophy of education. New York: Macmillan.

[7] Derrida, J., Caputo, D. J. (1997). Deconstruction in a Nutshell: A Conversation with Jacques Derrida. New York:
Fordham University Press.

[8] Dweck, S. C., Chiu, C., Hong, Y. (1995). Implicit Theories: elaboration and Extension of the Model. Psyichological Inquiry, 6 (4), 322-333.

[9] Eccles, M., Mason, J. (2001). How to developed costconscious guidelines. Health Technol Assess, 5 (16), 14-26.

[10] Gerbner, G. (1974). Media and symbols: the forms of expression, communication and education. The seventy-third yearbook of the national society for the study of education. Chicago: University of Chicago.

[11] Ginsburg, B. M. (1986). Reproduction, Contradictions, and Conceptions of Curriculum in Preservice teacher Education. Curriculum Inquiry, 16 (3), 283-309.

[12] Higashi, T. R., Tillack, A., Steinman, A. M., Johnston, C. B., Harper, G. M. (2013). The 'worthy' patient: rethinking the 'hidden curriculum' in medical education. Anthropol Med, 20 (1), 13-23.

[13] Howells, C. (1999). Deconstruction from Phenomenology to Ethics. Cambridge: Polity Press.

[14] Jackson, P. (1968). Life in classrooms. New York: Holt, Rinehart \& Winston.

[15] Jug Došler, A. (2012). Dvig kakovosti vzgojnoizobraževalnega dela $z$ raziskovanjem in usmerjanjem prikritega kurikuluma. Ljubljana: Filozofska fakulteta.

[16] Jug Došler, A., Mivšek, A. P., Petročnik, P., Škodič Zakšek, T. (2015). Subjektivne teorije in stališča kot kazalnika procesne ravni kakovosti v zdravstvu in socialnem delu. Socialno delo, 54 (6), 329-340.

[17] Katz, S., Sutherland, S., Earl, L. (2005). Towards an evaluation habit of mind: Mapping the journey. Teachers College Record, 107 (10), 2326-2350.

[18] Kecmanović, D. (2011). Conceptual discord in psychiatry: Origin, implications and failed attempts to resolve it. Psychiatria Danubina 23 (3), 210-222.

[19] Kelly, A. V. (2004). The Curriculum, Theory and Practice. London: SAGE Publications.

[20] King, N. (1986). Recontextualizing the Curriculum. Theory into Practice, 25 (1), 36-40.

[21] Kroflič, R. (2002). Izbrani pedagoški spisi. Ljubljana: Zavod SR za šolstvo.

[22] Mac Naughton, G. (2005). Doing Foucault in Early Childhood Studies. Applying poststructural ideas. London, NY: Routledge, Taylor \&Francis Group.

[23] Moore, J., Crozier, K., Kite, K. (2012). An action research approach for developing research and innovation in nursing and midwifery practice: building research capacity in one NHS foundation trust. Nurse Educ Today, 32 (1), 39-45.

[24] Moss, P., Dillon, J., Statham, J. (2000). The "child in need" and "rich child": discourses, constructions and practice. Critical Social Policy 20 (2), 233-254.

[25] Mossop, L., Dennick, R., Hammond, R., Robbé, I. (2013). Analysing the hidden curriculum: use of a cultural web. Med Educ, 47 (2), 134-143. 
[26] Norris, C. (2004). Deconstruction. London, NY: Routledge, Taylor\&Francis Group.

[27] Pajares, F. (1992). Teachers' Beliefs and Educational Research, Cleaning up a Messy Construct. Rewiew of Educational Research 62 (3), 307-332.

[28] Rose, A. D. (2016). Book Review: Global Perspectives on Adult Education and Learning Policy, by M. Milana and T. Nesbit (Eds.). Adult Education Quarterly, 67 (1), 66-68.

[29] Quigley, B. A., Holsinger, E. (1993). "Happy Consciousness": Ideology and Hidden Curricula In Literacy Education. Adult Education Quarterly, 44 (1), 17-33.

[30] Stenhouse, L. (1988). Case study methods. In: John, P. K. (ed.). Educational Research, Methodology and Measurement: An International Handbook. Sydney: Pergamon Press.

[31] Sternberg, J. R. (1999). Tacit Knowledge in Professional Practice: Researcher and Practitioner Perspectives. Mahwah, NJ: Lawrence Erlbaum Associates.
[32] Sandlin, J. A., (2000). The Politics of Consumer Education Materials Used in Adult Literacy Classrooms. Adult Education Quarterly, 50 (4), 289-307.

[33] Tuden, D., Gidora, H., Quick, D. P., Ebdon, N., Glover., K., Harmer, S., Miller Taylor, M., Borycki, M. E. (2013). Developing a strategy for studying critical thinking in a nurse telehealth setting: a participatory approach. Stud Health Technol Inform, 183 (1), 68-73.

[34] Shorey, M. J. (2013). Signal versus noise on the wards: what "messages" from the hidden curriculum do medical students perceive to be importantly meaningful?. Trans Am Clin Climatol Assoc, 124 (1), 36-45.

[35] Turnšek, N. (2008). Subjektivne teorije o otroštvu in vzgoji. Ljubljana: Pedagoška fakulteta UL.

[36] Yin, R. (2003). Case study research: design and methods. Thousand Oaks: Sage. 